\title{
AN EARLY PROTEROZOIC METAGRAYWAKE-SLATE TURBIDITE SEQUENCE: THE TAMPERE SCHIST BELT, SOUTHWESTERN FINLAND
}

\author{
RICHARD W. OJAKANGAS
}

\begin{abstract}
OJAKANGAS, RICHARD W., 1986: An early Proterozoic metagraywake-slate turbidite sequence: The Tampere schist belt, southwestern Finland. Bull. Geol. Soc. Finland 58, Part 1, 241-261.

The metasedimentary sequence of the Tampere Schist belt, where it has undergone only slight metamorphism, clearly consisted of graded graywackes, siltstones and mudstones. These rocks constitute a typical turbidite sequence, with the environment of deposition the mid-fan portion of a submarine fan. Most abundant are Facies $\mathrm{C}$ (proximal turbidites), D (distal turbidites) and $\mathrm{E}$ (overbank deposits). The source rocks were largely felsic volcanics, perhaps partly still unconsolidated and derived from nearby volcanic centers. Felsic plutonic detritus was derived from either subvolcanic plutons or from an unlocated basement complex. CIA values indicate that some detritus was unweathered and derived directly from volcanic centers, whereas other material had undergone moderate chemical weathering. Analyses of small-scale cross-beds suggest that the dominant sources were located to the east. A sedimentary-tectonic model involving deposition in a forearc basin on a subducting plate margin is likely.
\end{abstract}

Key words: metagraywacke, turbidite, geosynclinal, volcanogenic.

Richard W. Ojakangas: University of Minnesota, Duluth, Minnesota 55812 U.S.A.

\section{Introduction}

The rocks of the $200 \mathrm{~km}$ long Tampere schist belt are part of the larger Svecofennidic schist belt of western and southern Finland, a region of volcanic and sedimentary rocks separated by an abundance of felsic plutons. Well-preserved metasedimentary rocks exposed along the shores of Lake Näsijärvi north of Tampere were studied in detail by Simonen and Kouvo (1951), following up the early work of Sederholm (1897, 1913). Many geologists, including Seitsaari (1951), mapped in this region, and their work was incorporated into the $1: 100,000$ Viljakkala Teisko sheet by Simonen (1952, 1953 a). The Tampere area, which includes on Lake Näsijärvi the best preserved and least metamorphosed metasedimentary rocks, was mapped by Matisto $(1961 ; 1977)$ at the same scale. The existence of these maps, and especially the existence of the detailed field and laboratory study by Simonen and Kouvo, made this restudy of the best exposures of phyllite and metagraywacke on Lake Näsijärvi and nearby areas possible (Fig. 1).

Sederholm (1897) considered these well-bedded metasedimentary rocks to be varved schists, 


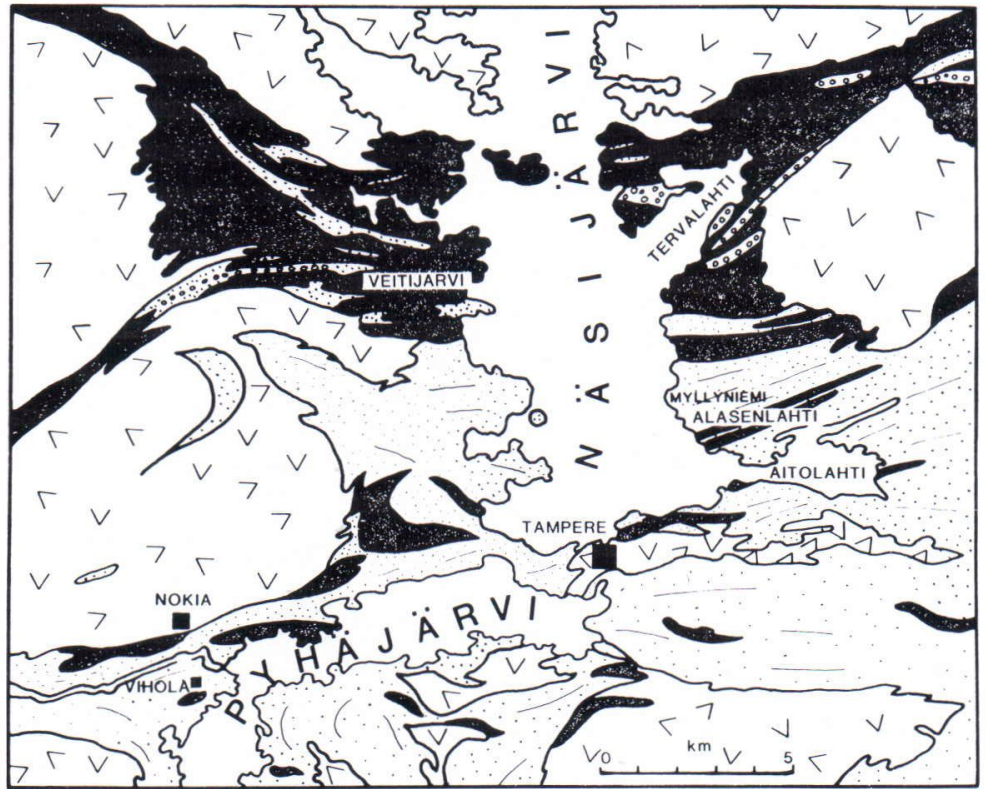

Fig. 1. Generalized geologic map of the Tampere area. Small sedimentary, volcanic and plutonic units are not shown. Graywacke-slate and mica schist shown by dotted pattern, conglomerates by small circles, volcanics by shaded pattern, and plutonics by the check pattern. After maps by Simonen (1953) and Matisto (1961). products of seasonal deposition similar to that which occurred in the Pleistocene. Eskola (1932) reinforced this interpretation; both stressed the actualistic concept of sedimentation. Pettijohn (1936, 1943) described similar metasedimentary rocks of Archean age in Ontario on the Canadian Shield, and emphasized their varved nature. As Simonen and Kouvo stated in their report, Pettijohn's work inspired them to do their detailed study.

All of the above cited work was accomplished before the turbidity current hypothesis for the origin of graded beds, as put forth by Kuenen and Migliorini (1950) and Kuenen (1950), was well-established and well-publicized. I had visited some of the classic outcrops with Ahti Simonen and Maunu Härme in 1961, and we discussed a possible turbidity current origin as already suggested by Simonen (1953 b, p. 35). The opportunity to look at the ice-polished and wavewashed exposures on the shores of Lake Näsijärvi once again, with the turbidite model in mind, came in the fall of 1982 when I was teaching at the University of Helsinki and working with the Geological Survey of Finland while on sabbatical leave.

\section{Stratigraphy and lithology}

The rocks under study here have appropriately been called schists or phyllites by previous workers. Because the grade of metamorphism is relatively low (upper greenschist facies) at Lake Näsijärvi, their original lithologies are easily determined to have been graywacke, siltstone, and mudstone. Metamorphism has transformed them into metagraywackes, metasiltstones and slates and/or phyllites. Because this report deals with the sedimentation of the original sediments, the pre-metamorphic terms will be frequently used.

These rocks form the lowest unit of the supracrustal succession that was named the Bothnian by Sederholm (1897), and are approximately $3000 \mathrm{~m}$ thick. The total succession, including arkose, conglomerate and volcanic rocks (dominantly mafic) is at least $8000 \mathrm{~m}$ thick (Simonen, $1953 \mathrm{~b}, 1980$ ). The major graywacke-mudstone accumulation is overlain by the major volcanic sequence (Simonen, 1980). Synkinematic quartz diorite, granodiorite and granite intrusions have penetrated the supracrustal succession (Seitsaari, 1951; Simonen, 1952, 1953 b; Matisto, 1961), 
and the grade of metamorphism varies with proximity to the plutons. Simonen (1953 b, p. 46) noted that the metasedimentary rocks of the Tampere area include the least metamorphosed rocks in the entire Svecofennian of Finland.

Isoclinal folding has resulted in numerous, generally east-west-trending, sub-horizontal fold axes in the schistose sequence, with beds dipping steeply $\left(70^{\circ}\right.$ to $\left.90^{\circ}\right)$ to the north and south, as mapped by Simonen and Kouvo (1951). They were able to correlate a few distinctive beds across the lake, a distance of about $6 \mathrm{~km}$. Regionally, the folds have wave lengths of a few hundred meters to a few kilometers (Simonen, 1953 b). Polyphase deformation has been mapped west of Lake Näsijärvi by Campbell (1980).

The steep attitudes of the beds on the icepolished and wave-washed lakeshore outcrops make possible the optimum viewing of crosssections of beds and uninterrupted sequences of beds. Simonen and Kouvo (1951) were able to measure the thicknesses of 4000 individual beds, and classified them as "thin-bedded varved schist» (less than $5 \mathrm{~cm}$ thick and usually less than $1 \mathrm{~cm}$ thick), and »normal varved schist» (greater than $5 \mathrm{~cm}$ thick and usually less than $20 \mathrm{~cm}$ thick). They called unusually thick beds, as thick as $2.8 \mathrm{~m}$, "megavarves.» Each of these three types is in reality two individual beds which in terms of varve theory, were thought of as closely related couplets. The »thin-bedded varved schist» usually consists of graded siltstone overlain, with a sharp contact, by mudstone. The »normal varved schist» and the "megavarves» consists of graywacke overlain by or grading upward into mudstone.

Conglomerates are well developed in one unit which is as thick as $900 \mathrm{~m}$ and which extends more or less continuously for $50 \mathrm{~km}$, from Veittijärvi west of Lake Näsijärvi (Fig. 1) to a point $35 \mathrm{~km}$ northeast of Tampere. However, this thickness is partially due to repetition by folding (personal communication, Yrjö Kähkönen, 1985). Seitsaari (1951) and Kähkönen and Laitakari (1983) have shown that the conglomerates con- sist largely of volcanic and hypabyssal rocks, with minor tuffitic, phyllitic, quartzitic and plutonic clasts. Seitsaari correctly called it a volcanic conglomerate.

Volcanic rocks are abundant in the northern part of the schist belt, but are found interbedded with the sedimentary rocks to the south as well. Excellent exposures of volcaniclastics, the dominant type of volcanic rock, are present in roadcuts along the main highway (Highway 9) 30 to $35 \mathrm{~km}$ northeast of Tampere (Seitsaari, 1951; Kähkönen and Laitakari, 1983). Most have calcalkaline affinities (Kähkönen, 1981, in Kähkönen and Laitakari, 1983), and are similar to modern island arcs in composition.

Many of the supracrustal rocks of the belt are now schists and gneisses. In a general way, this lower Proterozoic sequence resembles that on the southern margin of the Kisseynew sedimentary gneiss belt in northern Manitoba, Canada, where Bailes (1980) has described volcanogenic graywackes and mudstones that can be traced directly into paragneisses.

\section{Sedimentary structures}

There is an abundance of sedimentary structures in the graywackes and siltstones, all typical of turbidite sequences as described in the literature (e.g., Dzulynski and Walton, 1965; Ojakangas, 1968; Middleton and Hampton, 1973).

The most obvious feature is the bedding. Alternating beds of graywacke and mudstone maintain a constant thickness on an outcrop scale; this results in a marked parallelism (Figs. 2 and 3).

Such sequences of alternating beds are commonly interrupted by thin-bedded sequences (Figs. 4 and 5). The graded beds fit into the classic Bouma sequence (e.g., see Bouma, 1962, 1964); Figure 6 shows a Bouma A-B bed. Of the many hundreds of graded beds observed, only one reversely graded bed about $5 \mathrm{~cm}$ thick was noted. 


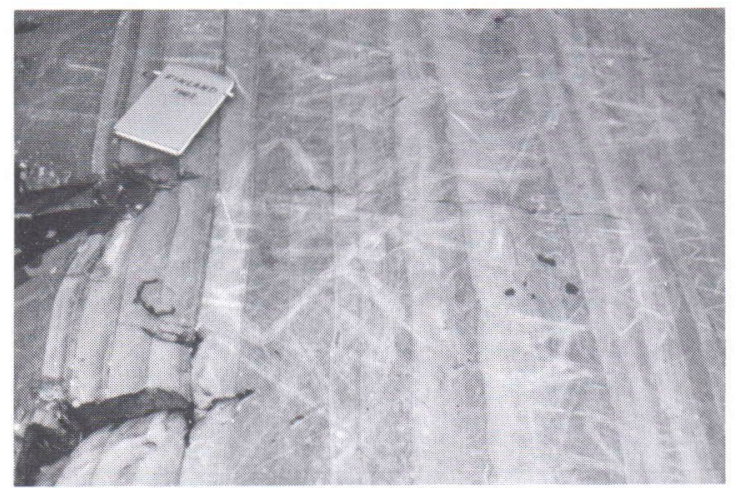

Fig. 2. Sequence of graywacke beds with subordinate mudstone beds (dark). Location is on west side of Lake Näsijärvi on southwest shore of Valkeekivenlahti, the third large bay north of Tampere.

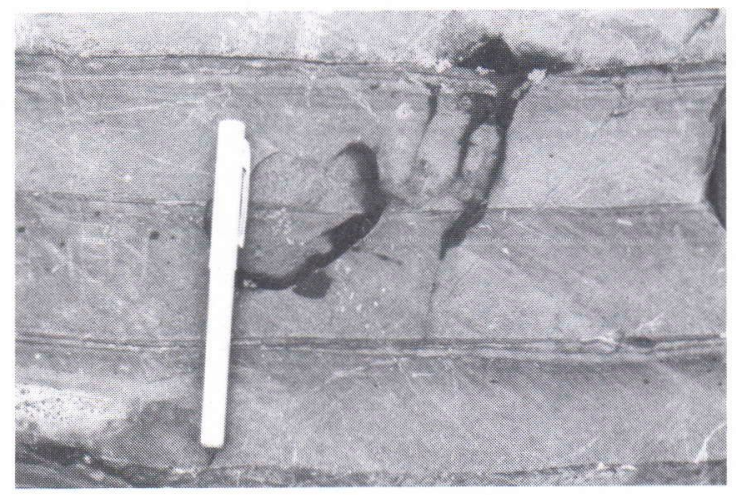

Fig. 3. Graded graywacke beds and minor mudstone beds. Same location as Figure 2.

Small-scale cross-beds are present in the $\gg \mathrm{C} \gg$ portion of some Bouma A-B-C beds (Fig. 7). However, most cross-bedding occurs in siltstone sequences that are not clearly parts of Bouma beds (Fig. 8).

Very few sole marks were observed, even though the bottoms of scores of beds were exposed in three dimensions; the few sole marks that were seen were not photogenic. The soles are extremely flat and smooth except for irregularities caused by the intersection of bedding and cleavage.

Soft-sediment deformational features are

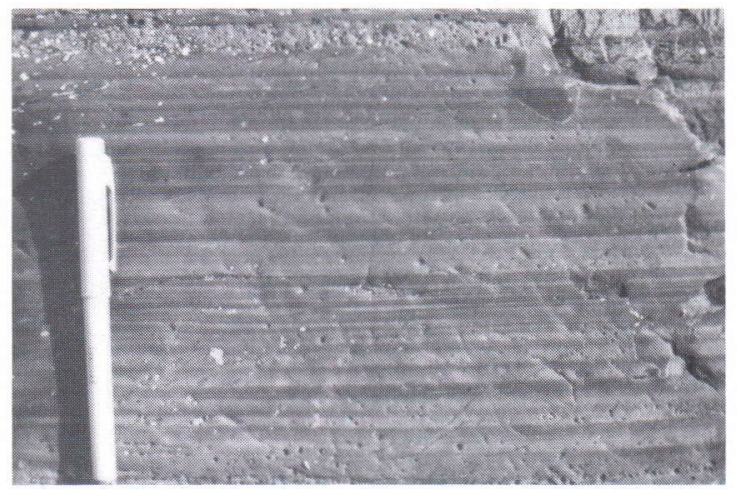

Fig. 4. Sequence of thin, laminated siltstone and mudstone beds. Location is on the east side of Lake Näsijärvi, at Savolahti, about $1.5 \mathrm{~km}$ north of Myllyniemi.

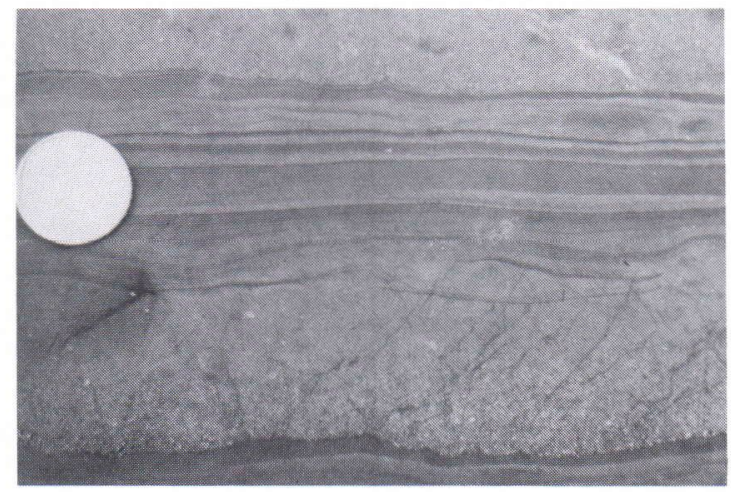

Fig. 5. Graded graywacke beds above and below thin sequence of siltstones and mudstones. Location is on the east side of Lake Näsijärvi at Jukonniemi, just south of Myllyniemi.

abundant, including loaded soles of graywacke beds (Fig. 9), clastic dikes (Fig. 10), and convoluted beds (Fig. 11). Some of the convoluted beds are more than $30 \mathrm{~cm}$ thick, with the beds above and below showing no deformation. Concretions are also present (Fig. 12), and can be confused with Corycium enigmaticum, a presumed fossil (Fig. 13) as described by Sederholm (1913), Matisto (1974) and others. Mudchips and siltstone fragments similar to interbedded mudstones and siltstones are present in many graywacke beds.

A continuous section $33 \mathrm{~m}$ thick on the east side of Lake Näsijärvi at Alasenlahti (northeast 


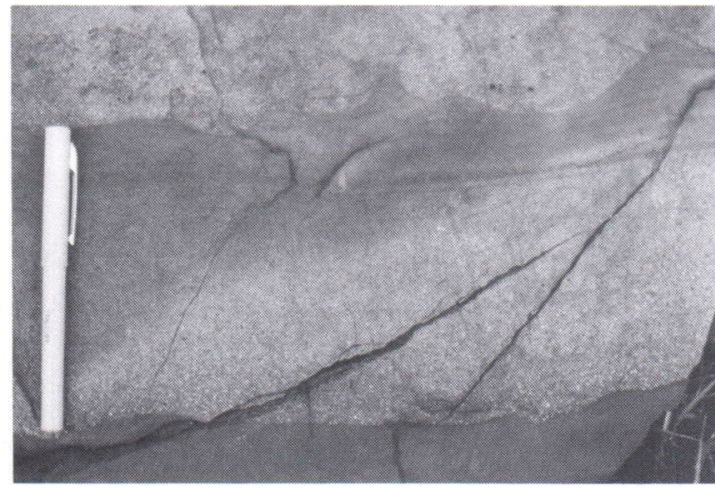

Fig. 6. Bouma AB graywacke bed overlain by another graded graywacke bed with soft-sediment load features at base. Location is same as Figure 5.

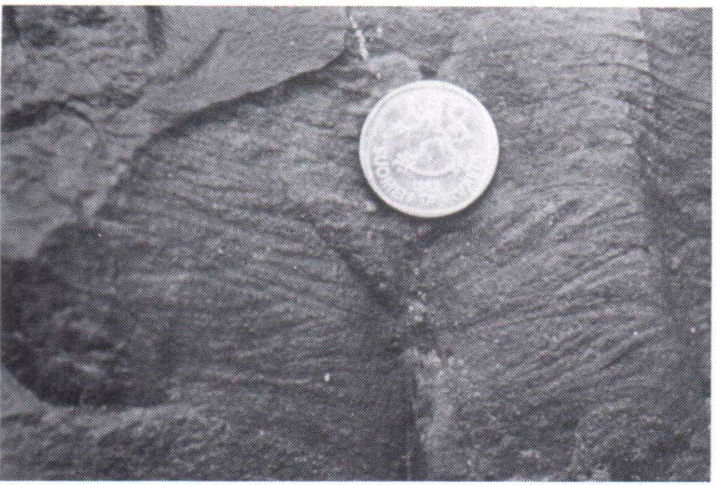

Fig. 7. Cross-bedded Bouma $\mathrm{C}$ portion of $40 \mathrm{~cm}$ thick Bouma $\mathrm{ABCD}$ graywacke bed. Location is northwest of Tampere in a roadcut on Highway $3,4.8 \mathrm{~km}$ northwest of the point where the highway leaves the Lake Näsijärvi shoreline.

shoreline), was studied bed-by-bed to ascertain bedding types and other sedimentary features. The sequence consists of 244 beds of which 162 are graywackes. Most graywackes are juxtaposed, but some are separated by thin mudstone and/or siltstone beds. Eight intervals with a total thickness of about $2 \mathrm{~m}$ and consisting of many very thin graywackes, siltstones, and mudstones were simply counted as single siltstone beds. Mudstone and siltstone beds total only 7 meters in thickness, so the »sand : shale ratio» is about $3.7: 1$.

Most of the graywacke beds are thin $(53 \%<$ $10 \mathrm{~cm} ; 24 \% 10-20 \mathrm{~cm} ; 6 \% 20-30 \mathrm{~cm} ; 4 \%$

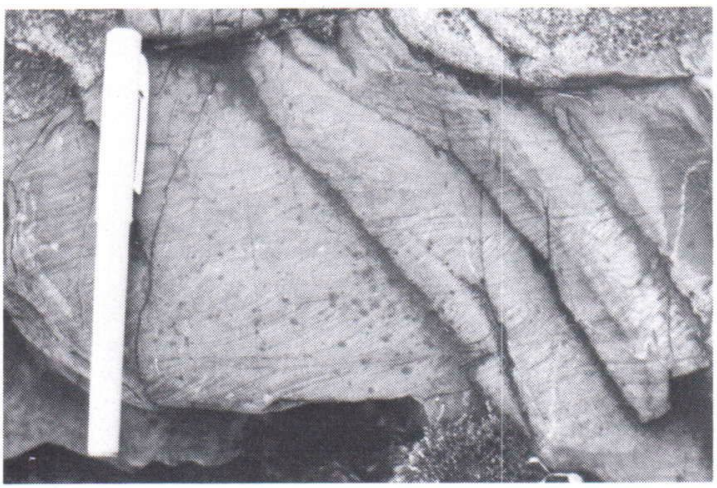

Fig. 8. Cross-bedded siltstone unit overlain by graywacke. Location is Alasenlahti on the east side of Lake Näsijärvi.

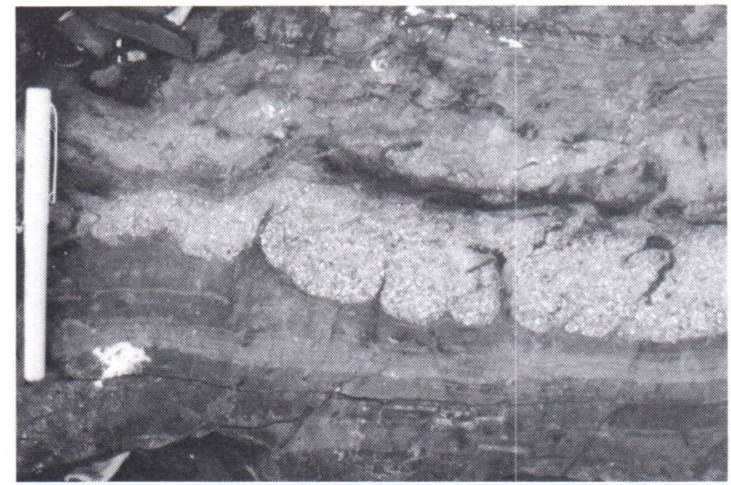

Fig. 9. Load casts and flame structures on base of lensoid graded graywacke bed. Location is same as Figure 8.

$30-40 \mathrm{~cm} ; 4 \% 40-50 \mathrm{~cm}$; and $4 \%>50 \mathrm{~cm}$ ); the latter number includes two beds that are 110 and $120 \mathrm{~cm}$ thick. These percentages are remarkably similar to summary data on 3589 "varves» presented by Simonen and Kouvo (1951); respective numbers are $58 \%, 29 \%, 8 \%$, $1 \%, 2 \%$, and $3 \%$, but these thicknesses include the graywacke beds plus the thin overlying mudstones.

A total of $94 \%$ of the graywacke beds are graded. The bases of most $(76 \%)$ of the beds are medium-grained sand; $20 \%$ have coarse-grained sand bases, and $4 \%$ have fine sand bases. The 


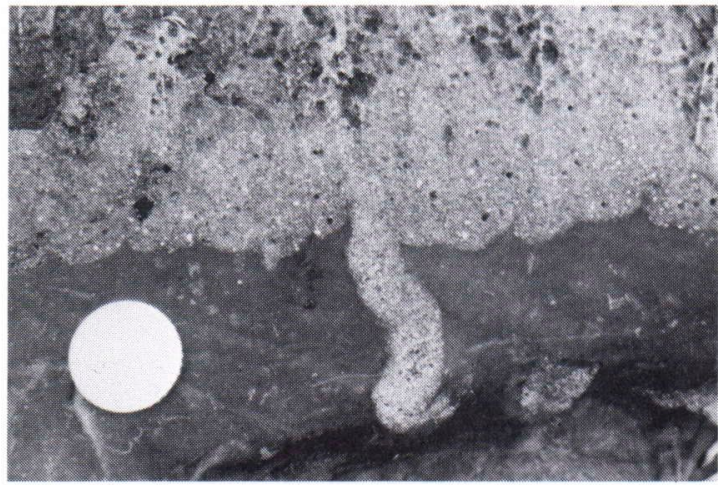

Fig. 10. Clastic dike cutting mudstone and graded graywacke bed. Location is same as Figure 5.

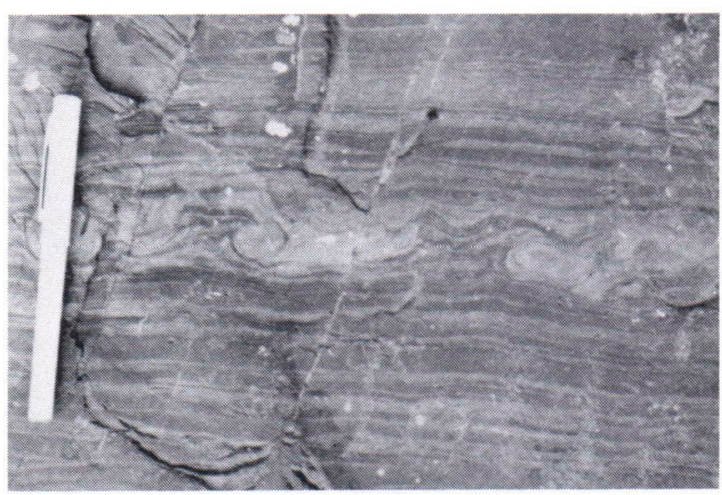

Fig. 11. Convoluted zone (soft-sediment deformation) in siltstone-mudstone sequence. Location is same as Figure 8.

graywacke beds fit well into the classic Bouma bed model for graded beds (Fig. 14); most are Bouma A or A-B beds. (Included with Bouma A beds are thin, 1 to $3 \mathrm{~cm}$ thick, Bouma $\mathrm{AE}$ beds which grade from sand into silt or clay.) A proximality index (Walker, 1967) of $\mathrm{p}=$ $\mathrm{A}+1 / 2 \mathrm{~B}$, where $\mathrm{A}$ is the percent of beds starting with the Bouma $A$ interval and $B$ is the number of beds starting with the Bouma B interval, is a high 95; if the AE beds are excluded, it is 80 .

One other continuous sequence was measured at Vihola, Nokia, southwest of Tampere (Fig. 15) because of the contrast it provides with the mea-

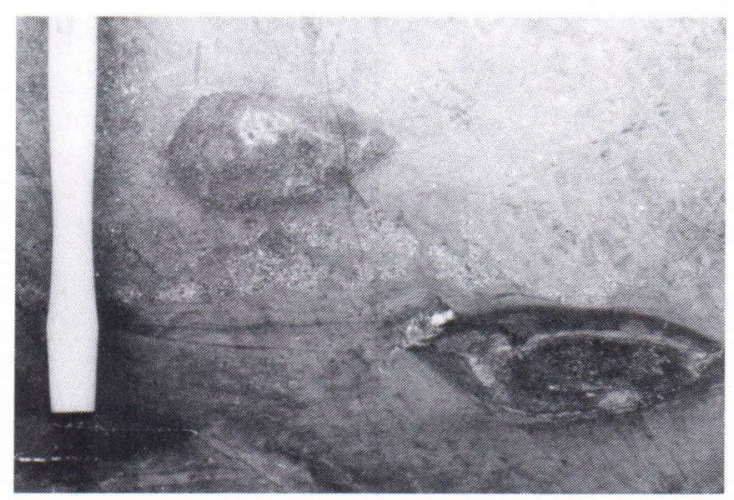

Fig. 12. Base of graded $1 \mathrm{~m}$ thick Bouma $\mathrm{AB}$ graywacke bed and top of Bouma B graywacke bed. Note loading and concretions. Location is southwest of Tampere at Vihola, Nokia.

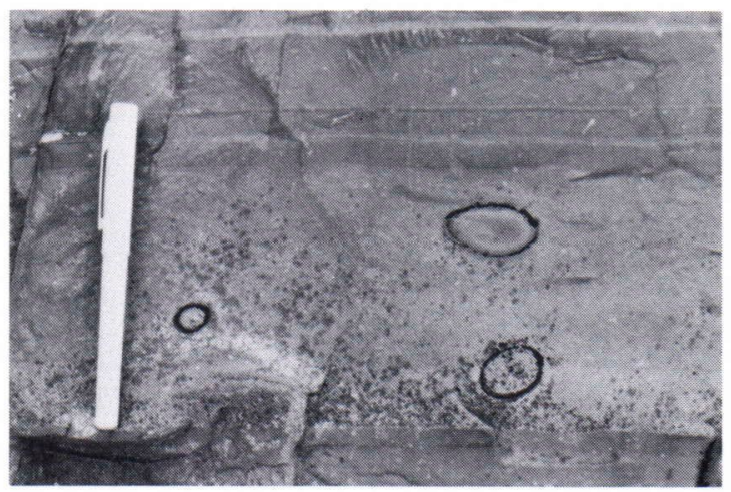

Fig. 13. Corycium enigmaticum in amalgamated graywacke bed. Location is on east side of Lake Näsijärvi at Myllyniemi.

sured section on the east side of Lake Näsijärvi. The $30 \mathrm{~m}$ thick section is the top part of a $60 \mathrm{~m}$ thick section that has a more tectonized lower half. It contains only 14 graded graywacke beds ranging in thickness from 40 to $500 \mathrm{~cm}$; thin mudstones (slates) are present between only a few of the beds. Nearly all of the graywackes are Bouma A, A-B or A-B-C beds.

Graded bedding is also present but less well developed in the volcanic-rich upper part of the supracrustal succession, as at Tervalahti, north of the excellent graywacke-mudstone sequence on the east side of Lake Näsijärvi. 


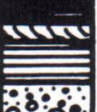

$\%$
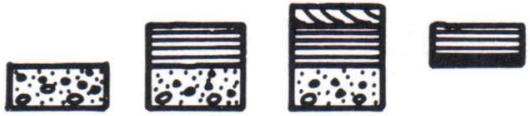

2

side of Lake Näsijärvi, and in numerous roadcuts east, west, and southwest of the lake. Unfortunately, the net result was a total of only 64 measurements, 60 on small-scale cross-beds and 4 on sole marks. The orientations of the crossbed and the master bed were measured, and a one-tilt rotation around the strike of the bed was performed on a stereonet. This simple one-tilt correction is permissible because the fold axes are nearly horizontal according to Simonen and Kouvo (1951), Simonen (1953 b), and personal observations. Similarly, the sole marks were rotated around the strike on the outcrop.

Although not abundant, the readings show a fairly good paleocurrent flow pattern toward the west (Fig. 16); most of the cross-beds, small trough-type structures on the order of 1 to $3 \mathrm{~cm}$ high, were measured from thin siltstone beds as illustrated in Figure 8. Five measurements on the east side of Lake Näsijärvi and 8 from the west side are from Bouma A-B-C or B-C beds, and

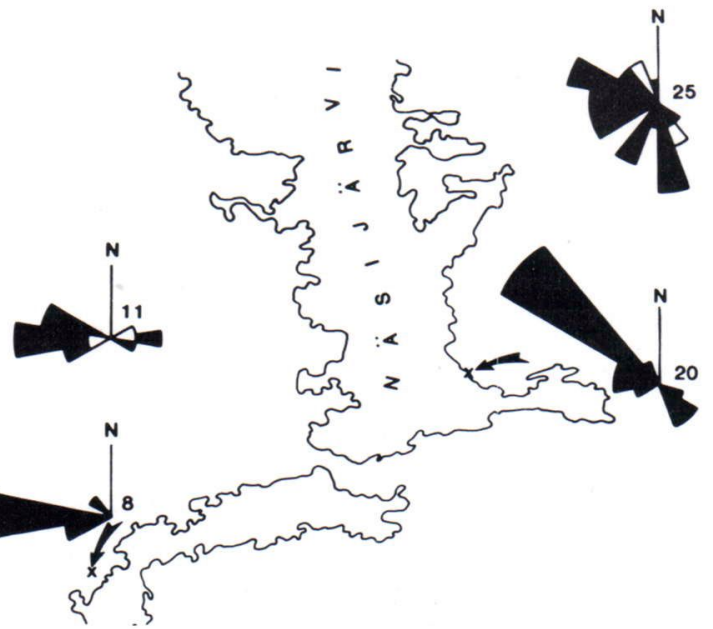

Fig. 16. Plots of paleocurrent measurements in graywackes and siltstones. The arrows adjacent to the two lower rose diagrams point to the locations at which those data were measured (see Figure 1). The upper two rose diagrams are plots of additional measurements at various localities on the east and west sides of Lake Näsijärvi. Black portions of roses represent small-scale cross-bedding; white portions indicate sole marks. The numbers indicate the numbers of measurements. 


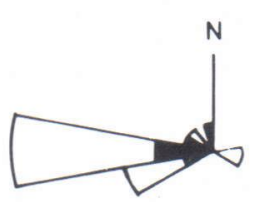

BOUMA $A B C$ or $B C$ BEDS

(15 READINGS)

SILTSTONES

(45 READIINGS)

SOLE MARKS

(4 READINGS)

Fig. 17. Plots of paleocurrent measurements by type. The upper rose diagram represents cross-beds measured in the $\mathrm{C}$ portions of Bouma $\mathrm{ABC}$ or $\mathrm{BC}$ beds. The middle rose represents measurements from siltstones. The bottom rose represents sole marks. The white portions of the roses represent measurements from the west side of Lake Näsijärvi, and black portions represent measurements from the east side.

have the same westerly trend (Fig. 17). Two additional measurements on the west side of Lake Näsijärvi, from a single Bouma $\mathrm{ABCD}$ bed which has a $15 \mathrm{~cm}$ thick $\mathrm{C}$ interval, are to the east, and are anamolous relative to the other readings (Fig. 17).

Although there are some easterly readings apparent in Figures 16 and 17, the large majority (75 percent) of the cross-bed measurements are westerly, as are numerous other cross-beds observed in the field but which could not be measured because they are exposed in only twodimensions. The four sole marks have a similar westerly orientation; the three groove casts (tool marks) do not give a sense but are oriented eastwest, and the one flute cast (scour mark) shows the current moved to the northwest, similar to the cross-beds.
The significance of the paleocurrent pattern will be discussed later in this report.

\section{Petrography}

The petrography of the graywackes has been described by Simonen and Kouvo (1951), Simonen $(1952 ; 1953$ b) and Matisto (1977). Additional observations are presented here on those rocks which have undergone the least metamorphism in order to allow more specific statements about the source areas.

Metamorphic recrystallization due to the numerous felsic intrusions has obliterated original clastic textures in many of the graywackes, transforming them into granoblastic mica schists and gneisses, commonly with porphyoblasts of aluminous silicates such as andalusite. Fortunately, such metamorphism, while resulting in new rock textures, has commonly not affected the major megascopic sedimentary features. For example, the original graywackes at Nokia are completely recrystallized to schists, but yet the bedding features are well preserved as illustrated in Figure 15.

Previous petrographic studies have shown an abundance of angular to subrounded quartz, plagioclase $\left(\mathrm{An}_{10-30}\right)$, and micaceous matrix; lesser amounts of microcline, sedimentary rock fragments (usually slaty but also quartzite), mafic and felsic (?) volcanic rock fragments, and minor heavy minerals are also present (Simonen and Kouvo, 1951; Simonen, 1952, 1953 b).

All of the above named components were observed during the present investigation, and some others were also noted. Point-counts of four of the least metamorphosed and least cataclasized graywackes are presented as Table 1. Even these thin sections, however, have been metamorphosed and recrystallized, and the counts obtained are to be utilized only as approximations of the original compositions. Perhaps the greatest problem is with the fine-grained felsic volcanic rock fragments, which because of the cited problems, 
Table 1. Model Analyses of Graywackes.

\begin{tabular}{|c|c|c|c|c|c|}
\hline Sample number: & 1 & 2 & 3 & 4 & Average \\
\hline $\begin{aligned} \text { Quartz } & - \text { Common } \\
& \text { - Polycrystalline }\end{aligned}$ & $\begin{array}{r}17 \\
5\end{array}$ & $\begin{array}{l}9 \\
3\end{array}$ & $\begin{array}{r}21 \\
2\end{array}$ & $\begin{array}{r}10 \\
3\end{array}$ & $\begin{array}{r}14 \\
3\end{array}$ \\
\hline $\begin{array}{c}\text { Feldspar }- \text { Plagioclase } \\
\text { - Orthoclase }\end{array}$ & $\begin{array}{l}1 \\
3\end{array}$ & $\begin{array}{l}2 \\
1\end{array}$ & $\begin{array}{l}5 \\
2\end{array}$ & $\begin{array}{l}6 \\
4\end{array}$ & $\begin{array}{l}5 \\
2\end{array}$ \\
\hline $\begin{aligned} \text { Rock fragments } & - \text { Volcanic, Felsic } \\
& - \text { Volcanic, Int.-Maf. } \\
& - \text { Plutonic (Plag-Qtz) } \\
& - \text { Plutonic (K-spar-Qtz) } \\
& - \text { Metamorphic (schist) }\end{aligned}$ & $\begin{array}{l}3 \\
\mathrm{X} \\
-1 \\
1\end{array}$ & $\begin{array}{r}10 \\
\mathrm{X} \\
2 \\
\mathrm{X} \\
-\end{array}$ & $\begin{array}{l}7 \\
1 \\
2 \\
5 \\
1\end{array}$ & $\begin{array}{l}4 \\
X \\
5 \\
- \\
-\end{array}$ & $\begin{array}{l}6 \\
\mathrm{X} \\
2 \\
1 \\
\mathrm{X}\end{array}$ \\
\hline Opaques & - & - & 3 & - & $\mathrm{x}$ \\
\hline $\begin{aligned} \text { Matrix } & - \text { Micaceous } \\
& - \text { Quartz-feldspar }\end{aligned}$ & $\begin{array}{l}54 \\
15\end{array}$ & $\begin{array}{l}38 \\
29\end{array}$ & $\begin{array}{l}33 \\
19\end{array}$ & $\begin{array}{l}49 \\
19\end{array}$ & $\begin{array}{l}44 \\
21\end{array}$ \\
\hline
\end{tabular}

Each count based on 600 points.

Samples 1 and 2 from east side Lake Näsijärvi.

Samples 3 and 4 from west side Lake Näsijärvi.

are commonly difficult to discern; many are probably counted as fine-grained quartz-feldspar matrix. The micaceous matrix, mostly biotite but including some muscovite and chlorite (Fig. 18), is interpreted as recrystallized clayey matrix.

The monocrystalline quartz grains are interpreted to be of plutonic origin but some could well be volcanic. Polycrystalline quartz grains (Fig. 19) are assumed to be of metamorphic origin, either recrystallized chert or recrystallized siltstone or sandstone, but some may be cataclasized monocrystalline grains. Those polycrystalline quartz grains with uncataclasized coarse-grained portions were counted as common (monocrystalline) grains. Individual grains of plagioclase (Fig. 20) and orthoclase (Fig. 21) could be of either plutonic or volcanic origin. Plutonic rock fragments consist of either quartz and plagioclase or quartz and K-feldspar (Fig. 21).

Felsic volcanic rock fragments are relatively common (Fig. 19); intermediate to mafic volcanic fragments (some originally glassy) (Fig. 20) are minor. Some volcaniclastic (tuff?) units interbedded with the graywacke-mudstone sequences consist nearly totally of felsic to intermediate volcanic rock fragments (Fig. 22). Graywackes interbedded with the volcanic-rich Veittijärvi conglomerate west of Lake Näsijärvi are also very rich in such fragments (Fig. 23).

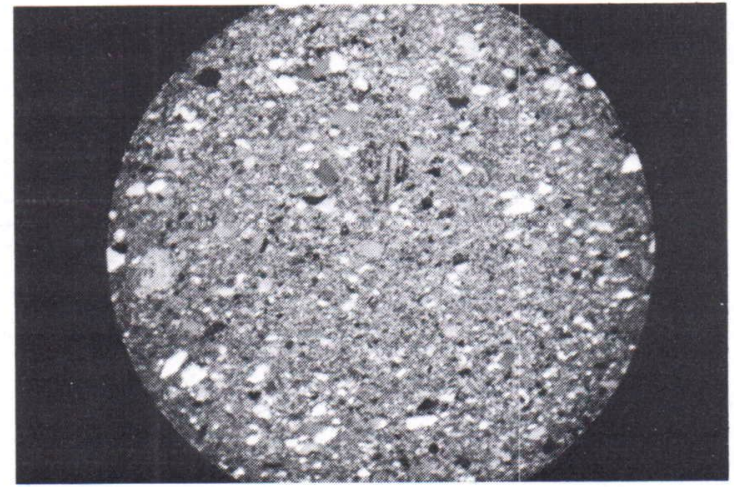

Fig. 18. Photomicrograph of matrix-rich graywacke from west side of Lake Näsijärvi. Field of view is $4.2 \mathrm{~mm}$ high.

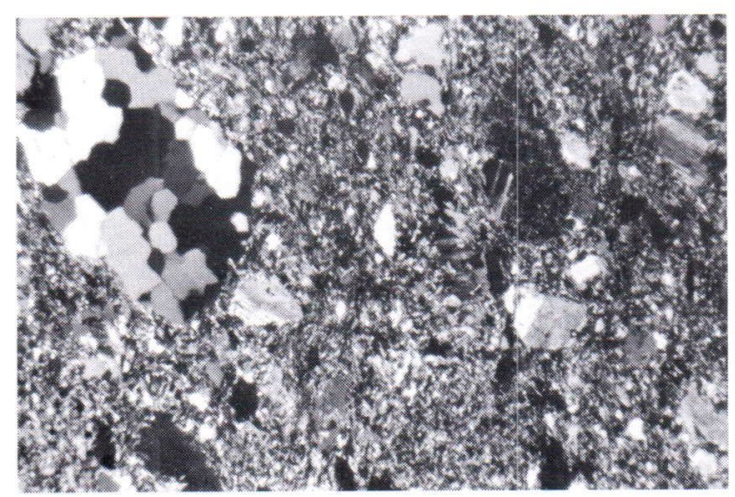

Fig. 19. Photomicrograph of graywacke with polycrystalline quartz grain at left and large felsic volcanic fragment with plagioclase phenocryst at right. Most of field consists of finegrained volcanic rock fragments. From east side of Lake Näsijärvi. Field of view is $1.7 \mathrm{~mm}$ high. 


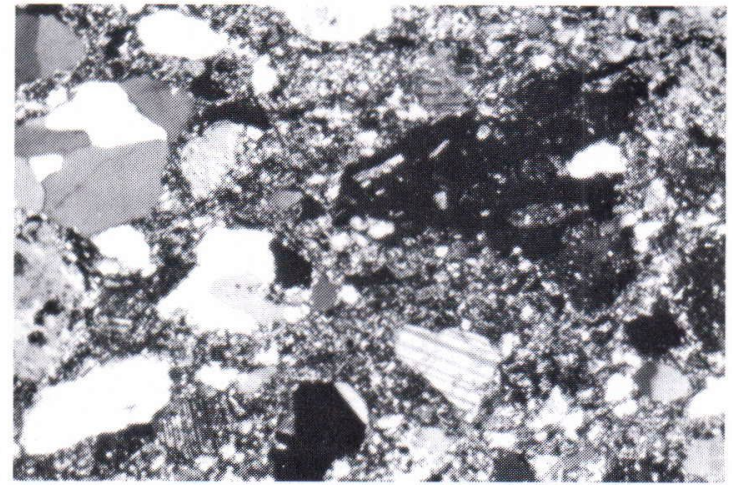

Fig. 20. Photomicrograph of graywacke with polycrystalline quartz grain at left, plagioclase at lower center, and dark porphyritic intermediate (originally glassy) volcanic fragment at right. Most of field consists of fine-grained volcanic rock fragments. From west side of Lake Näsijärvi. Field of view is $1.7 \mathrm{~mm}$ high.

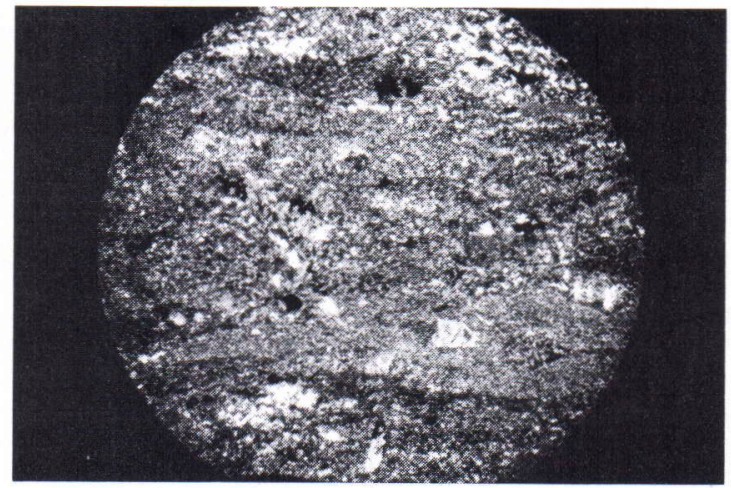

Fig. 22. Photomicrograph of felsic tuff-agglomerate interbedded with graywackes and mudstones on east side of Lake Näsijärvi on the north side of Aitolahti. Field consists of tectonically (?) elongated felsic volcanic rock fragments and mica. Field of view is $4.2 \mathrm{~mm}$ high.

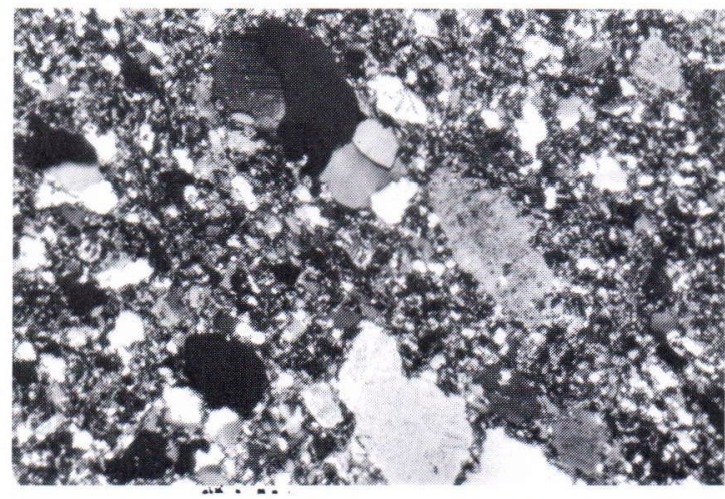

Fig. 21. Photomicrograph of graywacke with quartz-feldspar plutonic fragment at upper center, and altered orthoclase at center right and bottom. Most of field consists of fine-grained volcanic rock fragments. Same location as Figure 7. Field of view is $1.7 \mathrm{~mm}$ high.

Minor components include quartzite or metasandstone fragments (Fig. 24) and micaceous metamorphic rock fragments (Fig. 25).

\section{Chemistry}

A few chemical analyses of graywackes and mudstones (slates) from the Tampere schist belt are compiled in Table 2; several others were

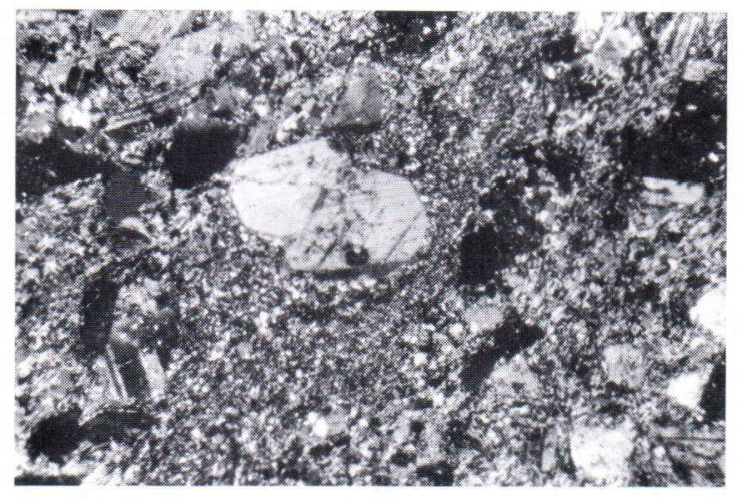

Fig. 23. Photomicrograph of volcanogenic graywacke sample from a $2.8 \mathrm{~m}$ thick Bouma $\mathrm{AB}$ bed that is interbedded with volcanic conglomerate. Large porphyritic felsic volcanic rock fragment crosses field from lower left to upper right. Note abundance of plagioclase grains. Location is Veittijärvi. Field of view is $1.7 \mathrm{~mm}$ high.

available, but they were labeled »varved schist» or "phyllite,» without a distinction made as to whether the sample was a graywacke or a mudstone and thus were not included.

Analyses of two slate-graywacke pairs (the »lighter and darker layers of the same varves»), analyses 1 and 2 and analyses 3 and 4 of Table 2, show that the graywackes are higher in $\mathrm{SiO}_{2}$ and lower in $\mathrm{Al}_{2} \mathrm{O}_{3}$ and $\mathrm{Na}_{2} \mathrm{O}$ than their associated slates; $\mathrm{CaO}$ and $\mathrm{K}_{2} \mathrm{O}$ contents are not 


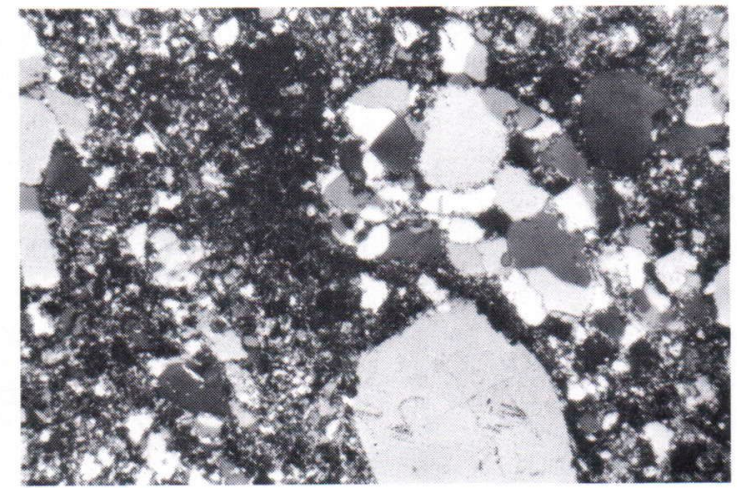

Fig. 24. Photomicrograph of graywacke with large monocrystalline quartz grain at bottom and quartzite rock fragment at center. Location is west side of Lake Näsijärvi. Field of view is $1.7 \mathrm{~mm}$ high.

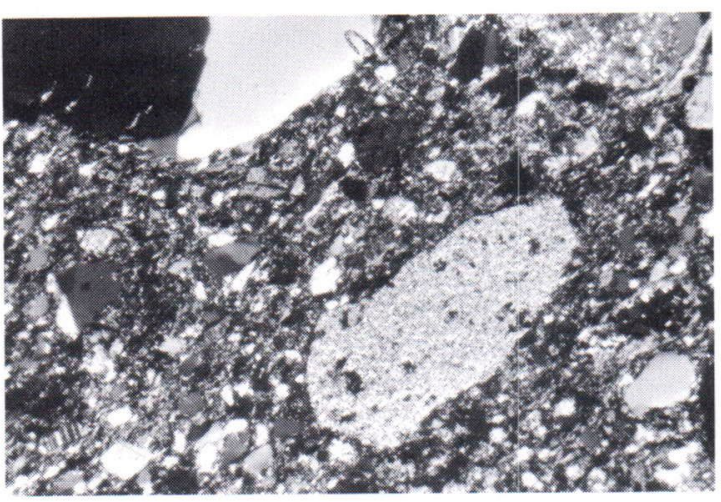

Fig. 25. Photomicrograph of graywacke with large quartz grain at top and metamorphic rock fragment composed completely of muscovite at center. Location is west side of Lake Näsijärvi. Field of view is $1.7 \mathrm{~mm}$ high.

Table 2. Chemical Analyses. Slates and Graywackes.

\begin{tabular}{|c|c|c|c|c|c|c|c|c|c|c|c|}
\hline & $\begin{array}{c}\text { Sl } \\
1\end{array}$ & $\begin{array}{c}\mathrm{Gr} \\
2\end{array}$ & $\begin{array}{c}\text { Sl } \\
3\end{array}$ & $\begin{array}{c}\mathrm{Gr} \\
4\end{array}$ & $\begin{array}{c}\mathrm{Gr} \\
5\end{array}$ & $\begin{array}{c}\text { Sl } \\
6\end{array}$ & $\begin{array}{c}\mathrm{Gr} \\
7\end{array}$ & $\begin{array}{c}\mathrm{S} l \\
8\end{array}$ & $\begin{array}{c}\mathrm{Gr} \\
9\end{array}$ & $\begin{array}{c}\mathrm{Sl}^{*} \\
10\end{array}$ & $\begin{array}{c}\mathrm{Gr}^{*} \\
11\end{array}$ \\
\hline $\mathrm{SiO}_{2}$ & 56.63 & 63.93 & 64.80 & 69.68 & 77.00 & 62.66 & 77.40 & 64.56 & 64.74 & 62.50 & 67.20 \\
\hline $\mathrm{TiO}_{2}$ & 1.04 & 0.82 & 0.50 & 0.50 & 0.42 & 0.85 & 0.34 & 0.61 & 0.54 & 0.68 & 0.52 \\
\hline $\mathrm{Al}_{2} \mathrm{O}_{3}$ & 22.41 & 16.92 & 17.51 & 14.71 & 11.32 & 18.62 & 10.79 & 16.99 & 15.64 & 19.10 & 15.60 \\
\hline $\begin{array}{l}\mathrm{Fe}_{2} \mathrm{O}_{3} \\
\mathrm{FeO}\end{array}$ & $\begin{array}{l}0.58 \\
5.05\end{array}$ & $\begin{array}{l}0.79 \\
5.04\end{array}$ & $\begin{array}{l}0.81 \\
3.34\end{array}$ & $\begin{array}{l}0.64 \\
2.62\end{array}$ & $\begin{array}{l}0.88 \\
2.02\end{array}$ & 7.15 & 5.26 & 5.44 & 5.89 & 7.38 & 6.86 \\
\hline $\mathrm{MnO}$ & 0.06 & 0.04 & 0.07 & 0.04 & 0.04 & 0.07 & 0.03 & 0.06 & 0.08 & 0.05 & 0.08 \\
\hline $\mathrm{MgO}$ & 2.35 & 2.15 & 1.36 & 0.92 & 0.68 & 3.19 & 1.60 & 3.21 & 2.83 & 3.14 & 2.72 \\
\hline $\mathrm{CaO}$ & 1.28 & 1.36 & 4.16 & 2.30 & 1.52 & 1.32 & 0.58 & 3.14 & 3.92 & 1.96 & 2.38 \\
\hline $\mathrm{Na}_{2} \mathrm{O}$ & 2.31 & 1.98 & 3.02 & 2.51 & 2.84 & 2.04 & 2.49 & 2.99 & 4.23 & 1.89 & 2.99 \\
\hline $\mathrm{K}_{2} \mathrm{O}$ & 6.15 & 4.94 & 3.70 & 4.92 & 1.68 & 4.13 & 1.47 & 2.72 & 1.98 & 2.83 & 1.57 \\
\hline $\mathrm{P}_{2} \mathrm{O}_{5}$ & 0.12 & 0.16 & - & - & 0.14 & 0.18 & 0.14 & 0.27 & 0.13 & 0.23 & 0.19 \\
\hline $\mathrm{H}_{2} \mathrm{O}^{+}$ & 2.19 & 1.43 & 0.72 & 0.96 & 1.05 & & & & & & \\
\hline $\mathrm{H}_{2} \mathrm{O}^{-}$ & 0.18 & 0.23 & 0.10 & 0.08 & 0.13 & & & & & & \\
\hline S & 0.08 & 0.02 & - & - & - & & & & & & \\
\hline $\mathrm{C}$ & 0.31 & - & - & - & - & & & & & & \\
\hline
\end{tabular}

1 \& 2. Ajonokka, Aitolahti (E. Side. L. Näsijärvi). Simonen and Kouvo, 1951, p. 101, \# 2 \& 3. These are from a graywacke and the overlying slate.

3 \& 4. Mansonsalmi, Ikaalinen, Huhma. Simonen, 1953, p. 32, \# 5 \& 11. These are from a graywacke and the overlying slate.

5. Ylöjärvi (W. Side L. Näsijärvi). Simonen and Kouvo, 1951, p. 101, \# 5.

6. Average of 12 Lower Proterozoic shales and slates, Minnesota. (Unpublished average, personal communication, G. B. Morey, Minnesota Geological Survey).

7. Average of 20 Lower Proterozoic graywackes, Minnesota. (See\#6).

8. Average of 6 Archean slates, Minnesota. (See \# 6).

9. Average of 42 Archean graywackes, Minnesota. (See \# 6).

10. Average of 14 Lower Proterozoic mudstones, Manitoba (Bailes, 1980).

11. Average of 9 Proterozoic graywackes, Manitoba (Bailes, 1980).

* Recalculated volatile-free to $100 \%$ by Bailes.

consistent relative to the slates. The $\mathrm{K}_{2} \mathrm{O}$ content exceeds $\mathrm{Na}_{2} \mathrm{O}$ in the slates and in two of the three graywackes. These relationships do not fit the generalities of graywackes and slates, for graywackes normally have high $\mathrm{Na}_{2} \mathrm{O}$ contents and associated shales have high $\mathrm{K}_{2} \mathrm{O}$ contents 
(Pettijohn, Potter and Siever, 1973, p. 211). Some analyses of slates and graywackes of comparable early Proterozoic age and of Archean age from Manitoba, Canada, and the Lake Superior region of Minnesota, U.S.A. are included in Table 2 for comparative purposes.

A CIA index, the chemical index of alteration, has been proposed by Nesbitt and Young (1982) as a measure of the chemical weathering of detritus in a sediment or sedimentary rock. The index is calculated by utilizing molecular proportions in the following formula: CIA = $\mathrm{Al}_{2} \mathrm{O}_{3}$ $\mathrm{Al}_{2} \mathrm{O}_{3}+\mathrm{K}_{2} \mathrm{O}+\mathrm{Na}_{2} \mathrm{O}+\mathrm{CaO} \times 100$. Corrections should be made for carbonate and apatite content, or the CIA values may be slightly low. In the present study, the data necessary for corrections were not available. It measures the ratio of the relatively insoluble $\mathrm{Al}_{2} \mathrm{O}_{3}$ to the soluble $\mathrm{K}^{+}$, $\mathrm{Na}^{+}$and $\mathrm{Ca}^{++}$ions. As the $\mathrm{K}^{+}, \mathrm{Na}^{+}$and $\mathrm{Ca}^{++}$ ions are removed, the CIA index will approach 100. Nesbitt and Young utilized the index of early Proterozoic glaciogenic deposits as a guide to weathering and hence to the climate at the time the sediment was formed and deposited. They cited values in the 80's and 90's for deeply weathered residual clays and for muds of the Amazon cone, and in the 50's and 60's for freshly contributed, cold-climate glacial sediment.

This index should also be useful as a comparative measure of the amount of weathering that sedimentary or volcaniclastic detritus has undergone by comparing the CIA values of the detritus to that of possible source rocks as well as to other sequences. (In the case of metasedimentary rocks, the metamorphism is assumed to have been isochemical). For example, Archean rocks from the Vermilion district of Minnesota, a 2700 Ma Archean volcanic-sedimentary greenstone belt, have CIA values as follows: three dacite porphyry dikes $=48.2$; three tuffs $=$ 47.9; and seven metasedimentary rocks (slates, metagraywackes and biotite schists) $=49.3$. This suggests little chemical weathering and a neariy direct derivation from felsic volcanic centers, as proposed on other petrographic and geologic evidence (Ojakangas, 1972; 1985). Andesites, basalts and ultramafics of the Vermilion district have even lower CIA values of 37 to 39 .

CIA values for the rocks of the Tampere area are presented in Table 3. The infracrustal and volcanic rocks have low values of 50.2 and 49.4 respectively. The average of 11 slates, graywackes and quartz-feldspar schists is 55.1, suggestive of very moderate weathering in the source areas if these plutonic and volcanic rocks of the area were the sources. This substantiates previous interpretations that the sediments are products of incomplete weathering (Simonen, 1980, p. 29).

Some local differences in CIA values can be seen in Table 3, and if it is assumed that the small number of chemical analyses available are indeed representative of the rock units, then some additional tentative conclusions can be drawn. For example, the graywacke and slate from Mansonsalmi, Ikaalinen (near Viljakkala, about $25 \mathrm{~km}$ west of Lake Näsijärvi), have values of 51.9 and 53.0, respectively. These are only slightly higher than the felsic volcanic rocks of the Ikaalinen area (48.9) and the Tampere area (49.4) and the plutonic rocks of the Tampere area (50.2), suggesting a rather immediate derivation as hypothesized above for Archean graywackes and slates in Minnesota. Volcanic rocks are abundant in the schist belt at Ikaalinen near the western end of the Tampere schist belt, and both the volcanics and the metasedimentary rocks have CIA values similar to the Minnesota Archean volcanics and metasedimentary rocks, indicating a similar volcanic derivation.

In contrast, the CIA values for the slate and graywacke on Lake Näsijärvi near Tampere are in the low 60's, quite similar to the Lower Proterozoic slates and graywackes of Minnesota (Table 3). The Proterozoic slates and graywackes of Minnesota were derived from weathered Archean granitic-greenstone terranes (Morey, 1967; Morey and Ojakangas, 1970). Perhaps the graywackes and slates of the Lake Näsijärvi sequence had a similar origin. However, the values for 
Table 3. Calculated CIA Indices (after Nesbitt \& Young, 1982; see text for explanation).

\begin{tabular}{|c|c|c|}
\hline Rock Type and Location & CIA & Reference for Chemical Analysis \\
\hline Slate, Tampere (1) & 63.7 & (Simonen \& Kouvo, 1951, p. 101, \# 9) \\
\hline Graywacke, Tampere (1) & 60.4 & (Simonen \& Kouvo, 1951, p. 101, \# 3) \\
\hline Slate, Mansonsalmi, Ikaalinen (1) & 53.0 & (Simonen, 1953, p. 32, \# 5) \\
\hline Graywacke, Mansonsalmi, Ikaalinen (1) & 51.9 & (Simonen, 1953, p. 32, \# 11) \\
\hline Graywacke, Tampere (1) & 55.0 & (Simonen \& Kouvo, 1951, p. 101, \# 5) \\
\hline $\begin{array}{c}\text { Average, } 11 \text { slates, graywackes and Q-F schists, } \\
\text { Tampere area }\end{array}$ & 55.1 & $\begin{array}{l}\text { (Above 5; Simonen \& Kouvo, 1951, p. } 101 \text {, } \\
\# 1 \text {, 4; Simonen, } 1953 \text {, p. } 32 \text {, \# 7; } \\
\text { Simonen, 1952, p. } 65 \text {, \# 4, 5, 7) }\end{array}$ \\
\hline Average, 2 volcanics (halleflinta and leptite), Tampere area & 48.7 & (Simonen, 1953, p. 33, \# $14 \& 15$ ) \\
\hline Average, 6 porphyries and porphyrites, Tampere area & 49.7 & (Simonen, 1952, p. 66, \# 14-19) \\
\hline $\begin{array}{ll}\text { Average, } & \text { above } 8 \text { volcanic rocks } \\
\text { Average, } 11 \text { infracrustals (intermediate to felsic), } \\
\text { Tampere area }\end{array}$ & $\begin{array}{r}49.4 \\
50.2\end{array}$ & (Simonen, 1952, p. 67, \# 20-30) \\
\hline Average, 3 porphyries, Ikaalinen area & 48.9 & (Simonen, 1953, p. 32-33, \# 31, 37, 46) \\
\hline Average, 12 Lower Proterozoic slates, Minnesota, USA & 64.5 & (See Table 2). \\
\hline Average, 20 Lower Proterozoic graywackes, Minnesota, USA & 61.5 & (See Table 2). \\
\hline Average, 6 Archean slates, Minnesota, USA & 55.6 & (See Table 2). \\
\hline Average, 42 Archean graywackes, Minnesota, USA & 49.1 & (See Table 2). \\
\hline Average, 14 Lower Proterozoic mudstones, Manitoba & 66.2 & (Bailes, 1980 , p. 218 , \# 5) \\
\hline Average, 9 Lower Proterozoic graywackes, Manitoba & 58.7 & (Bailes, 1980 , p. 218 , \# 1) \\
\hline
\end{tabular}

Lower Proterozoic slates and graywackes of Manitoba (Table 3) are also similar, and those are interpreted as having been eroded directly from easily eroded felsic pyroclastic deposits (Bailes, 1980).

Many more chemical analyses of the graywackes and slates of the Tampere schist belt would be of value in refining these hypotheses.

A relatively high $\mathrm{B}_{2} \mathrm{O}_{3}$ content in the slates and graywackes, compared to igneous rocks, was used as an indicator of marine deposition by Simonen and Kouvo (1951). The high boron content may also be an indicator of economic mineralization. For example, in the Proterozoic of British Columbia, magnesium-rich tourmaline occurs with stratiform lead-zinc ore, partly in meta-argillites and metaquartzites (Ethier and Campbell, 1977), and with gold in the Precambrian metasediments of Brazil (Fleisher and Routhier, 1973). Slack and others (1984) and Taylor \& Slack (1984) have summarized the occurrences of »stratiform tourmalinites» in Proterozoic and Paleozoic metamorphic terranes, and Henry and Guidotti (1985) have summarized the chemistry and petrology of tourmaline. The above workers propose the original boron to be syngenetic (submarine exhalative?) or diagenetic, and then mobilized and transported by hotspring and/or metamorphic fluids.

\section{Environment of deposition}

The interbedded graywackes, siltstones and mudstones are typical of turbidite sequences of Phanerozoic and Precambrian age. The importance of turbidity currents as a mechanism of transportation and deposition of graywackes on the continental slope and on submarine fans at the base of the slope is firmly established (e.g., Walker, 1975; Normark, 1978) despite the lack of modern observations of turbidity currents in action in a marine environment. Their importance in the resedimentation of volcanogenic detritus as volcanogenic graywackes in volcanic arc areas has also been stressed (e.g., Ayres, 1982; Sigurdsson, 1982 a, 1982 b; Ojakangas, 1985). The interbedded siltstones could be the product of normal ocean-floor currents, but it is more likely that they are Bouma C-D and D-E 
beds, the products of turbidity currents in distal locations relative to the source of the currents, or are overbank sediments deposited adjacent to the channels. This is substantiated by the agreement of the cross-bedding patterns in the siltstones and in Bouma ABC beds (Fig. 17). The Bouma beds were deposited by turbidity currents and are paleoslope indicators; because the siltstones show the same trends, then they were probably also deposited by currents that moved down the paleoslope. (Normal ocean floor currents, on the other hand, may move parallel to the paleoslopes and deposit »contourites» (e.g., Bouma and Hollister, 1973; Reineck and Singh, 1980, p. 482). The interbedded mudstones are accumulations of the normal deposition or "fallout» of clay from above during the intervals of time between turbidity current events. Thus, a turbidite bed was deposited in a geologic instant (minutes or hours or days) whereas a mud bed only a few centimeters thick may have taken centuries to form (e.g., Ojakangas, 1968).
The nature of a turbidity sequence reveals details on the relative locus of deposition within a submarine fan system (Fig. 26). On the upper reaches of the fan (the inner fan), conglomerates may be present in channels (Walker, 1975, 1979). Packets of thick and coarse-grained graywacke beds that have Bouma $\mathrm{A}$ intervals at their bases and an abundance of sole marks indicate deposition, commonly in channels, on the mid-fan. Conversely, a sequence of thinner and finergrained Bouma B-C beds indicates deposition at slower velocities on the more gentle slopes of the outer fan.

In the Lake Näsijärvi sequence, north of Tampere, the absence of conglomerates, the general lack of coarse sand, the generally thin beds, the lack of sole marks on the very flat bottoms of beds, and the minor importance of soft-sediment deformational features, together indicate deposition as proximal turbidites in a lower mid-fan area, following the models of Walker (1967, 1984), Walker and Mutti (1973) and Mutti and

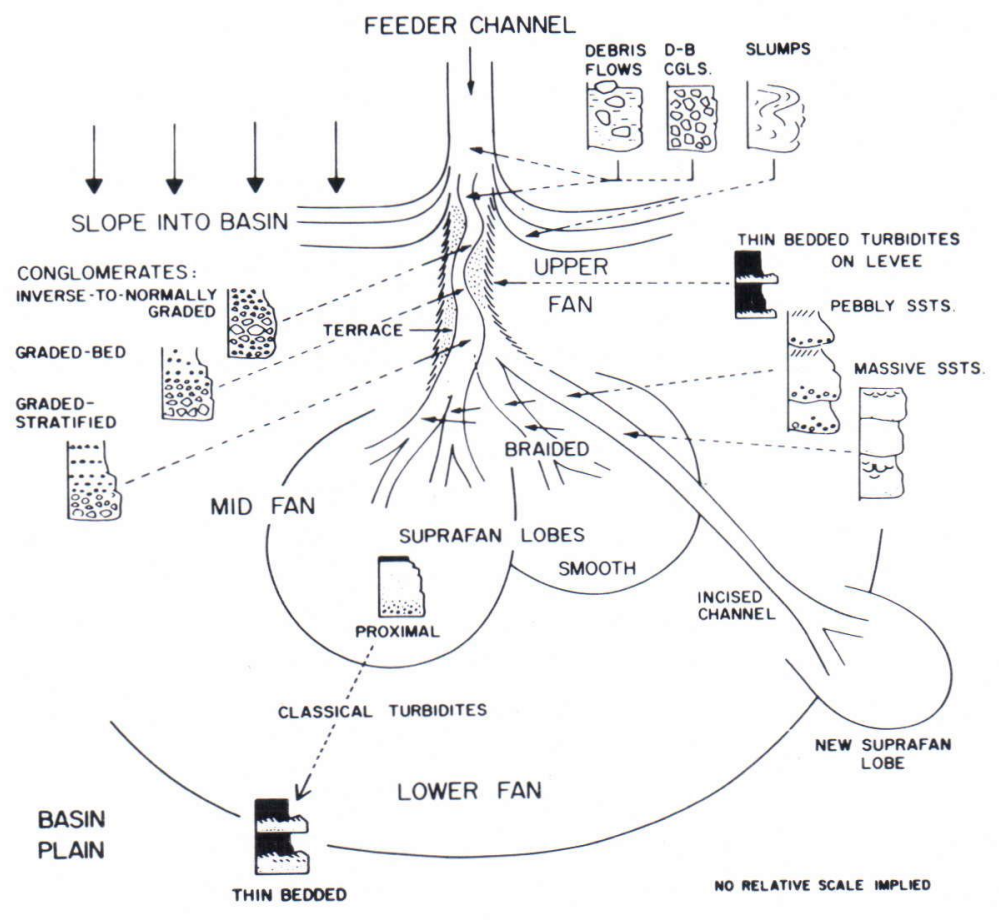

Fig. 26. Model of submarine-fan model. From Walker, 1979. Reproduced with permission of the Geological Association of Canada from R. G. Walker (1984). 
Ricci Lucchi (1978). However, such sandy sequences alternate with muddy sequences; for example, on the east side of Lake Näsijärvi, the sequence is sandy from Aitolahti to Myllyniemi, but north of Myllyniemi it is muddy.

Such changes may reflect tectonism in the source area; an increased supply of detritus may result in a coarsening upward sequence and fan progradation (e.g. Walker, 1984), whereas a diminished sediment supply could cause the pelagic muddy facies to cover the fan. Or, changes in sediment type may simply be reflecting channel migration on the fan. The sequence on Lake Näsijärvi can be classified as classical turbidites, deposits of Facies C (proximal turbidites), D (distal turbidites) and $\mathrm{E}$ (overbank deposits) of Walker and Mutti (1973) and Walker (1984). The high proximality index for the measured section also indicates that this packet of graywackes with a high sand : shale ratio was deposited in the mid-fan area (Fig. 26). Such a sequence may have been partially deposited in channels on the midfan, with the silty sequences being overbank deposits outside of the channels. However, the grain size and the moderate bed thickness indicate that most of the deposition may have been on outer suprafan lobes.

The thick and coarse graywacke beds at Nokia (Fig. 15) indicate deposition at a location nearer the source of the turbidity currents compared to the above measured section, probably localized in channels on the upper part of the mid-fan (Fig. 26). This sequence fits Facies C of Mutti and Ricci Lucchi (1978).

The conglomerate and graywacke unit at Veittijärvi west of Lake Näsijärvi (Figs. 1 and 23) may represent deposition in channels on the inner fan, as modeled by Walker $(1975 ; 1984)$. The arenaceous conglomeratic facies A of Mutti and Ricci Lucchi (1978) seems applicable.

The sequences at Lake Näsijärvi, Nokia, and Veittijärvi could all have been deposited on a single large submarine fan, for these areas are only about $15 \mathrm{~km}$ apart, and many modern submarine fans are measured in thousands of square kilometers. However, the structural relations are complex and the beds are all vertical and generally cannot be traced far. Therefore, the existence here of a single fan is strictly conjectural in the absence of better detail on the stratigraphic relationships of these sequences. Similarly, the structural complications are such that it has not been possible with the time available to determine vertical changes within the sequence. With detailed field studies in which structural and sedimentological data are integrated, it might be possible to establish the presence of prograding fan sequences and or other relationships. These environmental determinations must be considered tentative, as they are in any study of ancient rocks. Shanmugam and others (1985) have questioned the validity of the assignment of such environments of deposition to ancient turbidite facies, largely on the basis of the present lack of confirmation of such subfacies on modern fans. Furthermore, turbidites may accumulate around the edges of rapidly growing volcanic edifices, without the presence of submarine fans (Ojakangas, 1985).

The relatively high $\mathrm{B}_{2} \mathrm{O}_{3}$ content in the slates and graywackes, as mentioned earlier, was used as an indicator of a marine environment by Simonen and Kouvo (1951).

\section{Provenance}

The only previous interpretation of the location of the source areas relative to the Tampere schist belt was by Matisto (1977) who, on the basis of observations of bed thickness (thick to the south at Nokia and thinner to the north on Lake Näsijärvi), concluded that the source of the sediment was to the south. This has not been substantiated by the paleocurrent measurements of the present study.

The paleocurrent data (Figs. 16 and 17) suggest a possible dominant source area to the east and southeast, with minor sources to the west. However, two basic assumptions are necessary for this 
conclusion to be made. The first is that the fold axes in the region are indeed horizontal or nearly so, thereby eliminating the need for a two-tilt correction of the paleocurrent measurements; a review of the literature indicates that this is apparently so. The second assumption is that no major tectonic reorientation of the east-trending Tampere schist belt has occurred. This also appears to be true, for many volcanic-sedimentary (»schist») belts in southwestern and southern Finland show a similar trend (e.g., Simonen, 1980).

Yet, the interpretation of the source areas being situated to the east and west of the Tampere area may be invalid for another reason paleocurrents do not always point back to the source areas. Kuenen (1957) noted that many »flysch» basins appear to have been filled from the ends, rather than from the sides, with paleocurrent indicators parallel to the basin axes. McBride (1962) and Ojakangas (1968), among others, noted both longitudinal and transverse paleocurrent indicators within the basins that they studied. Ojakangas (1968) showed that on the west coast of Cretaceous North America, in spite of a dominant north to south paleocurrent trend, the Sierra Nevada to the east was the major source of sediment. Therefore, if the model of an elongate basin with longitudinal basin fill is used for the Tampere area, then the source areas could well have been situated to the north or south rather than to the east or west, with the paleocurrents turned in some way, probably by submarine topography, so as to parallel the basin axis.

The source areas for the graywackes and slates on Lake Näsijärvi included both felsic volcanic and felsic plutonic material in abundance, with minor mafic volcanic, sedimentary and metamorphic material also present (Table 1). The felsic volcanic sources appear to have been dominant.

What was the age of the plutonic and volcanic source terrane? Was it an older basement or a penecontemporaneous complex of magmatic rocks? Clearly, volcaniclastic units are interbedded in the graywacke-slate sequence, as il- lustrated on the Tampere and Viljakkala - Teisko mapsheets (Matisto, 1961; Simonen, 1953 b) and described in the map explanations (Simonen, 1952; Matisto, 1977). Surely the volcanic centers that were the source areas for the volcaniclastics and related rocks (Figs. 27 and 28) would also have supplied an abundance of sand-sized sediment via turbidity currents, and finer-grained clay and silt via normal suspension settling from the water column. The partial contemporaneity of volcanism and sedimentation of the graywackes and mudstones has been noted by several workers, including Simonen and Kouvo (1951), Matisto (1977), and Campbell (1980, in Kähkönen and Laitakari, 1983). The volcanic rocks range in age from 1920 to 1880 Ma (Simonen, 1980, p. 32-33). Recent samarium-neodymium studies (Huhma, 1985) also indicate that sedimentation in the Tampere area was at least partly contemporaneous with $1900 \mathrm{Ma}$ volcanism. Huhma further showed that a high proportion of the sediment was newly mantle-derived.

Detrital zircon from the graywacke at Nokia has been dated at about $2400 \mathrm{Ma}$ (Kouvo and Tilton, 1966; Simonen: 1980, p. 32), indicating that some basement (granitic?) terrane existed in the source area. Although no basement has been found for the Svecofennian volcanic-sedimentary complex (Simonen, 1980), the presence of the old zircon in the graywackes, a quartzite-pebble conglomerate near the eastern end of the Tampere schist belt (Seitsaari, 1951; Kähkönen and Laitakari, 1983); and quartzite clasts in the graywackes (Fig. 24) all indicate that basement was exposed somewhere in the source area. Seitsaari (1951, p. 42) has summarized such a hypothesis: »The existence of quartzite pebbles in a conglomerate proves, however, that a still earlier metamorphic rock crust must have existed. It is credible that the whole schist complex concerned has resulted from an intraformational deposition during the orogeny in question.» Also Wahl (1936, p. 500) has expressed the same opinion. The older Karelidic schist belt of northern and eastern Finland, $300 \mathrm{~km}$ to the 


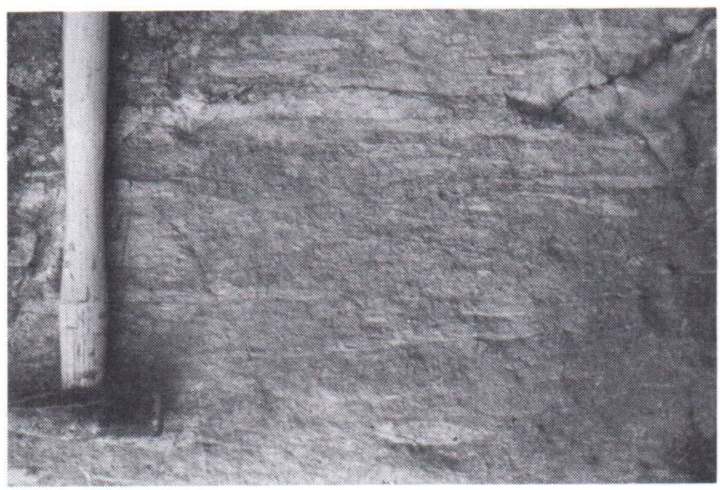

Fig. 27. Stretched felsic tuff-agglomerate interbedded with graywacke-slate sequence on the north side of Aitolahti. This is the same rock that is shown in the photomicrograph of Figure 22 .

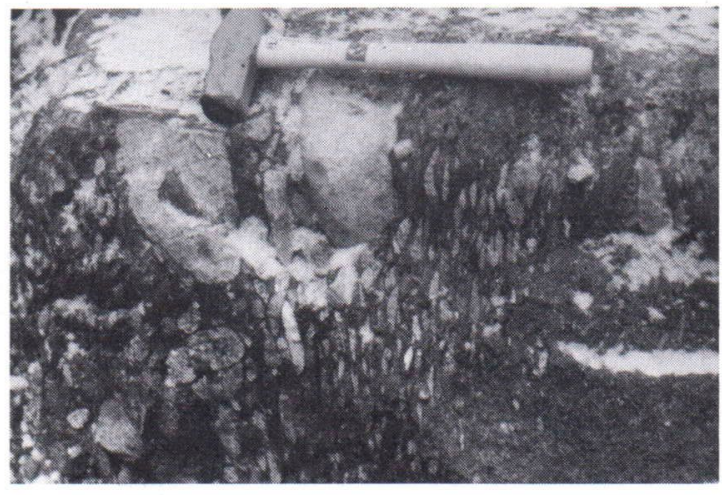

Fig. 28. Volcanic conglomerate in roadcut on Highway 338 on the east side of Lake Näsijärvi, south of Tervelahti.

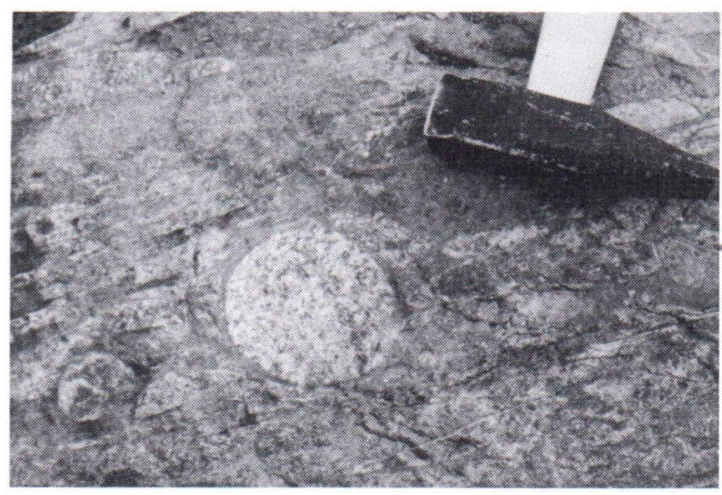

Fig. 29. Rare, felsic plutonic clast in volcanic conglomerate at Veittijärvi. northeast, comes to mind as a source of the quartzite, but such rocks may have existed in southern Finland as well. Perhaps a more likely source is the closer Tiirismaa Quartzite about $100 \mathrm{~km}$ north of Helsinki (Lehijärvi, 1962), a Jatulian-type quartzite perhaps related to a hypothetical basement (Laajoki, 1983).

Plutonic and hypabyssal pebbles in conglomerates of the Suodenniemi - Lavia schist zone $50 \mathrm{~km}$ west of Tampere have been interpreted as being derived from intergeosynclinal welts (Simonen, 1953 b, p. 36). Unless radiometric dating indicates that such plutonic clasts were derived from older basement rocks, at least some of them (Fig. 29) can as well be interpreted as having been derived from subvolcanic (coeval) plutons, such as have been documented in the Archean of the Canadian Shield (Ojakangas, 1985).

The cross-bedded arkose at Mauri, $25 \mathrm{~km}$ west of Tampere, is a body $2.5 \mathrm{~km}$ thick and $15-$ $20 \mathrm{~km}$ long. It has been interpreted by Matisto (1977) as locally derived from nearby granites and deposited in a fluvial-deltaic environment, and has been mapped by Matisto (1961) as passing laterally into the graywackes. This is reminiscent of relationships of some continental fluvial sandstones and deeper water turbidites of Archean age on the Canadian Shield, as reviewed by Ojakangas (1985). The age of the arkosic detritus at Mauri is about $1900 \mathrm{Ma}$, the approximate age of the plutons of the region (Matisto, 1977).

Some of the plutons of the region are approximately the same age (1850-1900 Ma) as the volcanic rocks, and plutonic pebbles in conglomerates have similar ages, strongly suggesting that some plutons were subvolcanic, coeval plutons. However, others are slightly younger (1750-1850 Ma) synorogenic plutons that clearly postdate the volcanism and sedimentation (Simonen, 1980, p. 32).

The limited chemical data, and especially the CIA values, indicate that two types of sediment were deposited in the Tampere region by turbidity currents. One type with lower CIA values was essentially unweathered volcanic material, probably 
contributed nearly directly to the basin from unconsolidated subaerial volcanic complexes. This type is analogous to early Proterozoic volcanogenic sediment in northern Manitoba (Bailes, 1980) and in the Archean of the Canadian Shield (Ojakangas, 1985).

The second type of sediment with higher CIA values was derived from a somewhat weathered terrane, probably one in which subvolcanic plutonic rocks had been unroofed and were being eroded along with lithified volcanic rocks and perhaps with some basement rocks as well. This terrane could have existed side-by-side with active explosive volcanoes during a continuum of volcanism, uplift, erosion and repeated volcanism. Such a scenario has been suggested for the Vermilion district of northeastern Minnesota where Archean volcanism, plutonism, and sedimentation were encompassed by an estimated 50 Ma time span (Sims, 1976).

\section{Tectonic-sedimentary model}

A eugeosynclinal model for the rocks of the Svecofennian schist belts of southern Finland has been put forth by Simonen and Kouvo (1951) and Simonen (1953 b, p. 59; 1980). The close relationships of volcanic, volcaniclastic and sedimentary rocks certainly indicate that this is a eugeosynclinal association in the classical sense. Gaal and Rauhamäki (1971) delineated eugosynclinal and miogeosynclinal zones in the Varkaus - Savonlinna area of southeastern Finland, at about the eastern end of the large Svecofennidic schist belt. They described in detail a portion of a metaturbidite sequence with Bouma intervals, similar to the turbidites of the Tampere area. A somewhat analogous complex of about the same age is found in the early Proterozoic of the Lake Superior region where volcanism and sedimentation culminated with the Penokean orogeny, as reviewed by Sims (1976).

In light of present-day plate tectonic theory, the proposed geosynclinal environment for the
Svecofennian schist belts has been updated by several workers, as follows. A comparison of the evolution of silicic magmas of the Sierra Nevada, California, and of the Svecofennian of southwestern Finland shows a distinct parallelism in both time and space (Hietanen, 1975). In both, synkinematic or potassium-poor trondhjemite and volcanic rocks were followed by potassiumrich granites and volcanics. The Mesozoic Sierra Nevada magmatic arc is thought to have been related to a subduction (Benioff) zone. By reason of this analogy and other evidence as well, it seems likely that a subduction zone of convergent tectonism existed in southwestern Finland in early Proterozoic time. Hietanen (1975) also stated that most of the metamorphic rocks of the Svecofennian belt were originally graywacke-type sediments with argillaceous and arenaceous layers and metavolcanic rocks. Mäkelä (1980) invoked a calcalkaline volcanic setting in a plate tectonicgenerated island arc as the site of deposition of Proterozoic ore bodies.

Pesonen and Neuvonen (1981) on paleomagnetic evidence, suggested that the Baltic and Canadian Shields may have collided about 1900 Ma, initiating the Svecokarelian and Hudsonian orogenies of the two shields. Presumably this event followed subduction as an ancestral ocean closed. Park \& Bowes (1981) and Gaal (1982) defined a major suture in southeastern Finland. Laajoki (1983) also briefly related the Svecofennian to an island arc system. A plate tectonic interpretation involving a northwardsubducting plate boundary has been proposed for the archipelago of southwestern Finland, part of the Svecofennidic complex, by Edelman \& Jaanus-Jarkkala (1983).

\section{Conclusions}

(1) The »phyllite» sequence of the Lake Näsijärvi area originally consisted of graded graywackes, siltstones and mudstones.

(2) These sedimentary rocks constitute a typi- 
cal turbidite sequence. Deposition generally took place in a lower mid-fan environment in relatively deep water below wave base. Facies present include Facies C (proximal turbidites), D (distal turbidites), and $\mathrm{E}$ (overbank deposits). Conglomeratic Facies A is locally present.

(3) The bulk of the sediment in the graywacke beds was probably derived from felsic volcanic sources. Interbedded volcaniclastics indicate the existence of an active volcanic arc nearby. Felsic plutonic detritus is also present, possibly derived from both subvolcanic plutons and from unlocated basement rocks.

(4) Calculation of chemical indices of alteration (CIA) for the graywackes and mudstones suggest that some material may have been derived directly from explosive volcanic centers, whereas other material underwent moderate chemical weathering.

(5) Paleocurrent analyses suggest, but do not prove, that the dominant source area was situated east of the present schist belt.

\section{References}

Ayres, L. D., 1982. Pyroclastic rocks in Precambrian greenstone-belt volcanoes: in Pyroclastic Volcanism and Deposits of Cenozoic Intermediate to Felsic Volcanic Islands with Implications for Precambrian Greenstone-Belt Volcanoes, ed. L. D. Ayres, Geol. Assn. Canada Short Course Notes v. 2, Winnepeg, p. 343-365.

Bailes, A. H., 1980. Origin of early Proterozoic volcaniclastic turbidites, south margin of the Kisseynew sedimentary gneiss belt, File Lake, Manitoba: Precambrian Research, v. 12 , p. $197-225$.

Bouma, A. H., 1962. Sedimentology of Some Flysch Deposits: Elsevier, Amsterdam, 168 p.

-, 1964. Ancient and recent turbidites: Geologie en Mijnbouw, v. 43, p. 375-379.

Bouma, A. H. \& Hollister, C. D., 1973. Deep ocean basin sedimentation: in Turbidites and Deep Water Sedimentation, ed., Middleton, G. V., Short Course Notes, Pacific Section, Society of Economic Paleontologists and Mineralogists, p. 79-118.

Campbell, D. S., 1980. Structural and metamorphic development of migmatites in the Svecokarelides, near Tampere,
(6) This turbidite-volcanic assemblage is similar to many plate margin rock associations from zones of subduction, as described in the literature. Deposition probably occurred on submarine fans in a forearc basin. The calc-alkaline composition of the volcanics is compatible with the subduction model.

Acknowledgements. Several persons made this study possible. Professor Ilmari Haapala of the Department of Geology, University of Helsinki, was instrumental in providing me with a visiting associate professorship for the fall of 1982. Dr. Jouko Talvitie of the Geological Survey of Finland provided a vehicle, field assistants, and field expenses. Yrjö Kähkönen of the Department of Geology guided me to several interesting outcrops in the schist belt. Heikki Reisbacka, Jussi Kuusala, and Veijo Pirhonen provided able assistance in the field. Lars Rämö made the thin sections. Joan Hendershot and Liz Metzen typed the manuscript and the repeated corrections. Ken Moran made black and white photographs from colored slides. To all of the above and to the many others whom I visited with in the field, at the University, and at the Geological Survey, I give my heartiest thanks!

Finland: Trans. Royal Soc. Edinburgh: Earth Sci., v. 71, p. $185-200$.

Dzulynski, S. \& Walton, E. K., 1965. Sedimentary Features of Flysch and Greywackes: Elsevier, Amsterdam, 274 p.

Edelman, Nils \& Jaanus-Jarkkala, Mirja, 1983. A plate tectonic interpretation of the Precambrian of the Archipelago of southwestern Finland: Geological Survey of Finland Bull. 325, 33 p.

Eskola, Pentti, 1932. Conditions during the earliest geologic times as indicated by the Archean rocks: Ann. Acad. Scient. Fenn. Ser. A. 36, 74 p.

Ethier, V. G. \& Campbell, F. A., 1977. Tourmaline concentrations in Proterozoic sediments of the southern Cordillera of Canada and their economic significance:

Can. J. Earth Sci., v. 14, p. 2348-2363.

Fleischer, Ronald \& Routhier, Pierre, 1973. The »consanguinous» origin of a tourmaline-bearing gold deposit: Passagem de Mariana (Brazil): Economic Geology, v. 68, p. $11-22$.

Gaal, G., 1982. Proterozoic tectonic evolution and late Svecokarelian plate deformation of the central Baltic Shield: Geol. Rund., v. 71, p. 158-170.

Gaal, G. \& Rauhamäki, E., 1971. Petrological and structural 
analysis of the Haukivesi area between Varkaus and Savonlinna, Finland: Bull. Geol. Soc. Finland, v. 43, p. 265 -337 .

Henry, D. J. \& Guidotti, C. V., 1985. Tourmaline as a petrogenetic indicator mineral: an example from the staurolite-grade metapelites of NW Maine: American Mineralogist, v. 70, p. 1-15.

Hietanen, Anna, 1975. Generation of potassium-poor magmas in the northern Sierra Nevada and the Svecofennian of Finland: Journal of Research, U. S. Geological Survey, v. 3 , p. $631-645$.

Huhma, Hannu, 1985. Provenance of some Finnish sediments: Geologi, v. 37, p. 23-25.

Kähkönen, Y., 1981. Oriveden ja Ylöjärven proterotsooiset vulkaaniset vyöhykkeet, erityisesti niiden geokemia: Unpublished thesis, University of Helsinki, 210 p.

Kähkönen, Y. \& Laitakari, I., 1983. Metavolcanics and metasediments of the Proterozoic Tampere schist belt: in Exogenic processes and related metallogeny in the Svecokarelian geosynclinal complex, eds. K. Laajoki and J. Paakkola, Geological Survey of Finland Guide 11, p. 110-134.

Kouvo, Olavi \& Tilton, G. R., 1966. Mineral ages from the Finnish Precambrian: Journal of Geology, v. 74, p. 421 -442 .

Kuenen, P. H., 1950. Marine Geology: Wiley, New York, 568 p.

—, 1957. Longitudinal filling of oblong sedimentary basins: Verhandel. Koninkl. Ned. Geol. Mijnbouwk. Genoot., Geol. Ser. 18, p. 189-195.

Kuenen, P. H. \& Migliorini, C. I., 1950. Turbidity currents as a cause of graded bedding: Journal of Geology, v. 58, p. $91-127$.

Laajoki, Kauko, 1983. Outlines of the Precambrian exogenic geology of Finland: Res Terrae, Ser. C, No. 3, University of Oulu, $46 \mathrm{p}$.

Lehijärvi, M., 1962. The quartzite area of Tiirismaa: Bull. Comm. geol. Finlande 204, p.

Mäkelä, K., 1980. Geochemistry and orgin of Haveri and Kiipu, Proterozoic strata-bound volcanogenic gold-copper and zinc mineralizations from southwestern Finland: Geological Survey of Finland Bull. 310, 19 p.

Matisto, Arvo, 1961. Geologic map of Finland, sheet 2123Tampere, Scale 1 : 100,000, Geological Survey of Finland.

,- 1974 . Corycium enigmaticum Beschaffenheit und Herkunft des Problematischen Gebildes: Geological Survey of Finland, Bulletin 268, 30 p.

-, 1977. Geological map of Finland, sheet 2123-Tampere, Summary: Precambrian rocks of the Tampere map-sheet area: Geologinen Tutkimuslaitos, $50 \mathrm{p}$.

McBride, E. F., 1962. Flysch and associated beds of the Martinsburg Formation (Ordovician), Central Appalachians: Journal of Sedimentary Petrology, v. 32, p. 39-91.

Middleton, G. V.\& Hampton, M. A., 1973. Sediment gravity flows: mechanics of flow and deposition: in Turbidites and deep water sedimentation, Society of Economic Paleontologists and Mineralogists (Pacific Section) Short Course, eds. Middleton, G. V. and Bouma, A. H., p. 1 -38 .

Morey, G. B., 1967. Stratigraphy and sedimentology of the Middle Precambrian Rove Formation in northeastern Minnesota: Journal of Sedimentary Petrology, v. 37, p. $1154-1162$.

Morey, G. B. \& Ojakangas, R. W., 1970. Sedimentology of the Middle Precambrian Thomson Formation, east-central Minnesota: Minnesota Geological Survey Rept. Inv. 13, $32 \mathrm{p}$.

Mutti, E. \& Ricci Lucchi, F., 1978. Turbidites of the Northern Apennines: introduction to facies analysis: International Geology Review, v. 20, p. 125-166.

Nesbitt, H. W. \& Young, G. M., 1982. Early Proterozoic climates and plate motions inferred from major element chemistry of lutites: Nature, v. 299, p. 715-717.

Normark, W. R., 1978. Fan valleys, channels, and depositional lobes on modern submarine fans: characters for recognition of sandy turbidite environments: American Association of Petroleum Geologists Bulletin, v. 62, p. $912-931$.

Ojakangas, R. W., 1968. Cretaceous sedimentation, Sacremento Valley California: Geological Society of America Bulletin, v. 79, p. 973-1008.

-, 1972. Archean volcanogenic graywackes of the Vermilion district, northeastern Minnesota: Geological Society of America Bulletin, V. 83, p. 429-442.

—, 1985. Review of Archean clastic sedimentation, Canadian Shield: Major felsic volcanic contributions to turbidite and ailuvial fan-fluvial facies associations: in Evolution of Archean Supracrustal Sequences, eds: Ayres, L. D., Thurston, P. C., Card, K. D., and Weber, Werner, Geol. Assn. Canada Sp. Paper 28, p. 23-47.

Park, A. F. \& Bowes, D. R., 1981. Metamorphosed and deformed pillow lavas from Losomäki: evidence of subaqueous volcanism in the Outokumpu association, E. Finland: Bull. Geol. Soc. Finland, v. 53, p. 135-145.

Pesonen, L. J. \& Neuvonen, K. J., 1981. Palaeomagnetism of the Baltic Shield ... Implications for Precambrian tectonics: in Precambrian Plate Tectonics, ed. A. Kroner, Elsevier, p. 623-648.

Pettijohn, F. J., 1936. Early Precambrian varved slate in northwestern Ontario: Geological Society of America Bulletin, v. 47, p. $621-628$.

-, 1943. Archean sedimentation: Geological Society of America Bulletin, v. 54, p. 925-972.

Pettijohn, F. J.; Potter, P. E. \& Siever, Raymond, 1973. Sand and Sandstone, Springer-Verlag, Berlin, 618 p.

Reineck, H. E. \& Singh, I. B., 1980. Depositional Sedimentary Environments, Springer, Verlag, 549 p.

Sederholm, J. J., 1897. Über eine archäische Sediment- 
An early Proterozoic metagraywacke-slate turbidite sequence: The Tampere schist belt, southwestern Finland

formation in südwestlichen Finnland und ihre Bedeutung für die Erklärung der Entstehungsweise des Grundebirges: Bull. Comm. geol. Finlande, v. 6, 1897.

-, 1913. Suomen geologinen yleiskartta: Lehti B2 Tampere, Kivilajikartan selitys.

Seitsaari, Juhani, 1951. Schist belt northeast of Tampere, Finland: Bull. Comm. geol. Finlande 153, 120 p.

Shanmugam, G.; Damuth, J. E. \& Moiola, R. J., 1985. Is the turbidite facies association scheme valid for interpreting ancient submarine fan environments? Geology, v. 13, p. $234-237$.

Sigurdsson, H., 1982 a. Volcanogenic sediments in island arcs: in Pyroclastic Volcanism and Deposits of Cenozoic Intermediate to Felsic Volcanic Islands with Implications for Precambrian Greenstone-Belt Volcanoes, ed. L. D. Ayres, Geol. Assn. Canada Short Course Notes v. 2, Winnipeg, p. 221-293.

-, 1982 b. Subaqueous volcanogenic sediments in ocean basins: in Pyroclastic Volcanism and Deposits of Cenozoic Intermediate to Felsic Volcanic Islands with Implications for Precambrian Greenstone-Belt Volcanoes, ed. L. D. Ayres, Geol. Assn. Canada Short Course Notes v. 2, Winnipeg, p. 294-342.

Simonen, Ahti \& Kouvo, Olavi, 1951. Archean varved schists north of Tampere in Finland: Bulletin de la Commission Geologique de Finlande 154, p. 93-114.

Simonen, Ahti, 1952. Geological map of Finland, sheet 2124, Viljakkala - Teisko, Explanation to the map of rocks: Geologinen Tutkimuslaitos, $74 \mathrm{p}$.

-, 1953 b. Stratigraphy and sedimentation of the Svecofennidic, Early Archean supracrustal rocks in southwestern Finland: Bulletin de la Commission Geologique de Finlande, No. 160, 64 p.
—, 1953 a. Geologic map of Finland, sheet 2124-Viljakkala — Teisko, scale 1: 100,000, Geological Survey of Finland.

—, 1980. The Precambrian in Finland: Geological Survey of Finland Bulletin 304, 58 p.

Sims, P. K., 1976. Precambrian tectonics and mineral deposits, Lake Superior region: Economic Geology, v. 71, p. $1092-1127$.

Slack, J. F.; Herriman, Neil; Barnes, R. G. \& Plimer, I. R., 1984. Stratiform tourmalinites in metamorphic terranes and their geologic significance: Geology, v. 12, p. 713 -716 .

Taylor, B. E. \& Slack, J. F., 1984. Tourmalines from Appalachian - Caledonian massive sulfide deposits: Textural, chemical and isotopic relationships: Economic Geology, v. 79 , p. $1703-1726$.

Walker, R. G., 1967. Turbidite sedimentary structures and their relationship to proximal and distal depositional environments: Jour. Sed. Petrology, V. 37, p. 25-43.

,- 1975 . Generalized facies models for resedimented conglomerates of turbidite association: Geological Society of America Bulletin, v. 86, p. 737-748.

,- 1984 . Facies models 8 . Turbidites and associated coarse clastic deposits: in Facies Models, 2nd revised edition, ed. Walker, R. G., Geoscience Canada Reprint Series 1, p. 171-188. (Reprinted with revisions from Geoscience Canada, v. 3, p. 25-36.)

Walker, R. G. \& Mutti, E., 1973. Turbidite facies and facies associations: in Turbidites and Deep-Water Sedimentation, ed. Middleton, G. V., Short Course Notes, Pacific Section, Society of Economic Paleontologists and Mineralogists, p. 119-157. 